\title{
Postmodern Dönemde Yeni Bir Tanım Arayıș: Müellif Olarak Grafik Tasarımcı
}

Umut ALTINTAŞ*

Altıntaş, U. (2020). Postmodern Dönemde Yeni Bir Tanım Arayışı: Müellif Olarak Grafik Tasarımcı. YEDİ, 23, 87-96, doi: 10.17484/yedi.632878

Araştırma Makale / Research Article

Özet

Modernizmin zorunlu getirisi olarak metnin ve içeriğin üreticisi olmaktan çok, görsel iletişim aracısı konumunda durmuş olan grafik tasarımcılar, 1970’li yıllara gelindiğinde içeriğin şeffaf iletkeni görevini üstelenen modernist tasarım anlayışının reddi ile birlikte müşteriden bağımsız ve kişisel inisiyatife dayalı tasarım eğilimlerine yönelmeye başlamışlardır. Bu eğilim, designer as author olarak tanımlanan ve Türkçede müellif tasarımcı kelimesine karşılık gelen bir anlayışını beraberinde getirmiştir. Müellif tavır ile birlikte grafik tasarımcılar için içerik üretimi, tasarım sürecinin en başından itibaren, biçimle birlikte düşünülmesi gereken bir bileşen haline gelmiştir. Böylelikle grafik tasarımcılar, mesleki becerileriyle birlikte kişisel birikimlerini de tasarım sürecine dahil etmeleri gerektiğini keşfetmişlerdir.

Anahtar Sözcükler: Müellif, grafik tasarımcı, postmodernizm, içerik, yazarlık.

\section{In Search Of New Definition In The Postmodern Era: Graphic Designer As An Author}

\section{Abstract}

Graphic designers, who have stood in the position of visual communication mediator rather than being the producer of text and content as a necessary return of modernism, started to turn towards design tendencies independent of the customer and personal initiative based on the rejection of the modernist design concept which assumed the role of transparent conductor of the content in 1970s. This tendency has brought along an understanding which is defined as designer as author and corresponds to the word müellif in Turkish. With this author attitude, the production of content has become a component that must be considered together with the form for graphic designers, from the very beginning of the design process. Thus, graphic designers have discovered that they need to incorporate their professional knowledge as well as their personal knowledge into the design process.

Keywords: Author, graphic designer, postmodernism, content, authorshipm. 


\section{Bir Tasarım Biçimi Olarak Yazarlık}

Grafik tasarımda yazarlık tanımı, esasen tasarım disiplininin dışında, edebiyat ve felsefe alanında tohumları atılmış iki kurama dayanmaktadır. Bu kuramlar Roland Barthes'in 1968 yılında yayımladığı Yazarın Ölümü (Barthes, 2013) isimli makalesini ve Michel Foucault'un 1969 yılında bir ders olarak işlediği ve ardından metinleştirildiği Yazar Nedir? (Foucault, 1998) isimli çalışmalardır. Bu iki metin, postmodern dönemin koşullarına bağlı olarak yazarlık ve onun beraberinde getirdiği otorite kavramını odağa alarak metin, yazar ve okuyucu üçgeninde metnin anlamını sorgulamaktadır. Edebiyat dünyasını çok yakından ilgilendiren bu iki makale, ileriki yıllarda grafik tasarım alanındaki gelişmelerin kuramsal zeminine de büyük katkı sağlamıştır.

Tasarımcıların kendi üretim pratiklerini entelektüel açıdan sorgulamaya başladıkları zamana ilişkin yazar olarak tasarımcı (the designer as author) fikri, ilk olarak Mayıs 1991 yılında Blueprint dergisinde Rick Poynor tarafından kaleme alınmıştır. Poynor (1998, s. 99) bu denemesinde 1980 sonrası yetişen genç tasarımcılar için müşterinin isteklerini kendi üslubuyla iletme yolunun fazlasıyla benimsendiğini dile getirmektedir. Tasarımcı, kişisel üslubuyla işi sahiplenmeye başlamıştır. Süssüz, açık, doğrudan fikir ileten tasarım anlayışı bir kenara bırakılmış, çok katmanlı metin dizgileri ve okunaksız, karmaşık görsel alanlarıyla oluşturulan bir dil benimsenmiştir. Artık kendine özgü, imza olarak adlandırılabilecek bir tasarım anlayışıyla da müşterinin sorunları çözülebilir hale gelmiştir.

Grafik yazarlık, en basit tabirle tasarımcının mesajını veya görüşünü, müşterinin ona verdiği temel malzemelere yeni bir katman, yorum ve referans ekleyerek ifade etmesi olarak tanımlanabilir. Böylesi bir yaklaşım kültürel alana hizmet eden tasarım mecraları için daha uygun olmakla birlikte ticari örnekleri de bulunmaktadır. Tasarımdaki yeni algı gelişmeleri, onu hizmet sunmak için var olan bir meslekten çıkartıp yeniden ele alınması gereken derin bir probleme dönüştürmektedir.

Müellif olarak tasarımcı fikri, Poynor'un akabinde, Michael Rock'ın (1996) Eye dergisinde aynı başlıkla yazdığı makalesiyle birlikte tasarım alanları çevresinde daha çok duyulan ve tartışılan bir konu haline dönüşmeye başlamıştır. Makalede geçen 'grafik yazarlık' tanımlaması, geleneksel yöntemle mesajın oluşturulmasından çok iletilmesiyle ilişkilendirilmiş ve Rock, grafik tasarım mesleği içerisindeki tasarım sürecine yeni bir yaklaşım önermiştir. Rock'a göre tarih boyunca değişen yazar kelimesi, anlamının tam karşılığı olan yazarlık mesleği için bile dönüşüme uğramıştır.

Author, yani Türkçe karşılığıyla müellif, herhangi bir şeye kök veya varoluş veren kişi anlamına gelmektedir. Bunun yanı sıra ataerkil, mucit, kurucu, başlatan gibi otoriter bir tanıma da sahiptir (Rock, 1996). Ne var ki müellif yerine yazar kelimesini kullandığımızda author kadar güçlü bir anlama karşılık gelmemektedir. Karol'a (2006) ${ }^{1}$ göre İngilizce'de ise author ve authority, yani yazar ve otorite arasında doğrudan bir ilişki bulunmaktadır. Dolayısıyla bu yazıda author kelimesinin karşılığı olarak müellif kelimesini kullanacağız.

Michael Rock (1996) tasarımciyı müellif olarak adlandırırken, Roland Barthes'in 1968 tarihli Yazarın Ölümü denemesine atıfta bulunmakla birlikte, 1960’larda ölümü ilan edilen bir kavramı 1990’larda tasarımcı için yeni bir tanımlama olarak atfetmiştir. Yazarın ölümü, özellikle postmodern çağ tanımlarının dayanağı olan sahipsizlik ve dilsizlik söylemleriyle yazar figürünü tersine çeviren ikincil bir okuma sunmaktadır. Barthes'in kuramına göre yazılan eserde yazarın neyi ifade ettiği değil, onu nasıl ifade ettiğidir ve metin asıl anlamını okuyucuyla birlikte kazanır. Barthes bu ünlü makalesinde "bir metnin bütünlüğü kökeninde değil ulaştığı yerde bulunur.” (2013, s. 68) diye söz etmektedir. Dolayısıyla metin, yazarın yazdığı biçimde değil, okuyucunun onu yorumladığı biçimde anlamlandırılabilmektedir.

Basma ve yayımlama kültürü içerisinde yazının değişime uğraması, yazarın görevini ve okuma biçimlerini de doğrudan etkilemiştir. Yazıyı zamana hapsedilmiş bir ürüne çevirmek ve postmodern dönemde metni, farklı birçok sosyal yapıda insana açık bir biçimde yaymak, yazarı metnin sahipliğinden çıkarmış, okuyucuyu metnin asıl sahibi konumuna getirmiştir. Dolayısıyla Barthes'e göre yazarın ölümü, okuyucunun da doğuşu gerçekleşmiştir.

Modern yazı, kendi varlığını gösterebilmek adına yazarını ortadan kaldırmayı amaçlar. İlkel toplumlarda metni sunan kişilerin metnin sahibi değil yalnızca bir aracı olarak bulunmalarının aksine yazar, Ortaçağ sonrası aydınlanmada bireyin önemini keşfeden toplumun yarattığı bir kişi olmuştur. Dolayısıyla okunan metnin anlamı da yazarın kişiliğinden ve sesinden koparılamaz, yazarı Tanrı mertebesine yerleştirir. Yazar, her zaman yazı veya kitabın geçmişi olarak algılanmaktadır. Ancak Barthes bu görüşe

\footnotetext{
1 Esen Karol ile Uğur Tanyeli Arasında Bir E-posta Söyleşisi isimli bu kaynak artık çevrimiçi mecralarda yer almadığından ilgili makaleye yazar ile yapılmış kişisel görüşme ile ulaşılmıştır.
} 
karşı çıkar:

(...) karşısında konuşan kişilerin sağırlığını da duyan biri vardır. İşte o kişi kesinlikle okurun kendisidir. Yazının tüm varlığı da bu şekilde kendisini gösterir. Metin, farklı kültürlerden gelen, birbirleriyle diyalog kuran, kavga eden, birbirlerinin parodisini yapan çok sayıda yazıdan oluşur; ancak bu çokluğun bir ayara gelip toplandığı bir nokta vardır ve bu nokta, yazarın kendisi değildir, okurun kendisidir (...) bir metnin bütünlüğü, kökeninde değil, ulaştığı yerde bulunur (...) (Barthes, 2013, s. 67). Barthes'in denemesinin sşık tuttuğu Michel Foucault'un Yazar Nedir? bildirisinde ise Foucault yazarı, okuyucunun metne ulaşmasına sayısız biçimde yön verebilecek işleve sahip bir kişi olarak görmektedir. Yazar ile yazdıkları arasındaki bağlantı biçim değiştirmiş ve odak, yazarın niyetinden çok yazının kendi iç işleyişine; yani yazının ne anlama geldiği değil, o anlama nasıl geldiğine dönmüştür (Foucault, 1998).

$\mathrm{Bu}$ fikirden hareketle denebilir ki tipografi ve sayfa yapısıyla değiştirilen ana metin, kavramın kökenine doğrudan müdahale etmekte ve onu dönüştürmeye başlamaktadır. $\mathrm{Bu}$ da bir biçimde yeniden yazmaktır. Lupton'un da ifade ettiği gibi grafik yazarlık, işin içeriğinde değil, tasarlanma biçimiyle ilgilidir. Tasarım yazmanın, yazı da tasarımın bir biçimidir (Lupton, 2009).

1970 ve 80’li yıllarda tasarımda anlam ve işlevin sorguya çekilmesi ve dijital üretim sürecinin de estetiğe nüfuz etmesiyle birlikte, kişiliğinden ve yorumundan vazgeçmiş bir ara iletici olan tasarımcının da rolü değişime uğramıştır. Rock’a (1996) göre içerikten bağımsız bir mesaj üretme yetkisi olmayan tasarımcılar, yazar tanımı atfedildikten sonra dışarıda tutuldukları tüm yetkileri geri almışlardır. Tasarımın içeriğini sorgulamışlar veya kendileri içerik yazmayı tercih etmişlerdir. Tasarımcılar, tasarım işlerine kendi eleştirel bakış açısıyla yaklaşmış, ortaya çıkardıkları grafik ürünün tasarım diliyle kendi sosyal veya felsefi düşüncelerini de iletme dürtülerini açığa çıkarmışlardır.

Rock'un sözünü ettiği müellif tasarımcı kavramı, postmodern süreçle birlikte metin üzerinde anlam üreten kişi olarak yerini almıştır. Doğrudan metnin içine karışma ve yorumlama, metnin, tasarımcıların şeffaflığı aracılığıyla kendisini göstermesini gerektirmektedir. Yazarın ortadan kaybolmasıyla doğan boşluğu tasarımcı ona bırakılan metinle doldurmaktadır. Yazarın yokluğu, tasarımcının kendi yorumlama ve yazma sürecini dahil ederek doldurabileceği tasarım alanı sağlamaktadır. Tasarımcının metin üzerine yeniden yazdığı, yani biçimsel olarak yorumladığı tasarımlar, yeni anlamlar doğurmaktadır. Rock’a (1996) göre tasarımcının ürettiği her yeni anlam, yazarın geride bıraktığından daha farklı olacağından, içeriğin kuracağı iletişime de doğrudan etki etmektedir.

Müellif tasarımcı tanımlaması, grafik tasarımcıların kendilerine sordukları biz aslında ne yapıyoruz? sorusunun da bir cevabıdır. Bu cevap, gerçek anlamda yazma eyleminden öte, tasarımcının bir işi yaparken kendi inşa ettiği üsluba dayalı bir müelliflik kavramından gelmektedir: "Müşteriden bağımsız bir bakış açısına sahip tasarımcı; müşterinin iletmek istediği mesajın da üzerinde olan, tasarımcının kendi mesajı” (Lupton, 2009). Müellif kelimesinin gücü, yazılmış metinle olan bağlantısında yatmaktadır. Tasarımcıların içeriği ve işin sosyal işlevini ele alabilmeleri için birer müellif olmaları gerekmektedir. Tasarımcı için müellif olmak, içeriği yönetme ve iletişimin aktığı sosyal, estetik ve teknolojik sistemleri kullanabilme becerisine sahip olmak anlamına gelmektedir. Müellif olarak tasarımcılar ürettiği ve yayımladığı iş aracılığıyla 'anlamı' açığa çıkaran kişilerdir. Tasarımda yazarlık, tasarım sürecinde, mesajın kökeninden okuyucuya aktarılmasında yeni yaklaşımlar öneren bir girişimdir (Lupton, 1998, s. 161).

\section{Bir Geçiş Süreci}

Tasarımcının mesajı, yani tasarım aracılığıyla söylenecek sözü sahiplenmesi, 20. yüzyılın son çeyreği ile birlikte, dünyanın daha küresel bir hale gelmesi, kitle iletişim araçlarının daha yaygın ve demokratik olması ve bu konu üstüne kuramların yaygınlaşmasına dayanmaktadır. Postmodern dönemin eklektik dinamiği tasarımcının kimliğini ve işlevini yeniden tanımlamak için çok doğru bir zamanlama olsa da birkaç on yıl öncesine kadar böyle bir kimlikten söz etmek o kadar kolay değildir.

20. yüzyıl ile birlikte, tasarım ve iletişim kavramlarının ilk defa bir mesleğe işaret ettiği ve kitle iletişim araçlarının teknolojik gelişmelere demokratikleşmeye başladığı dönemlerde grafik tasarımcılar, sosyal gelişmeler paralelinde toplumla iletişim kurma yollarını bu yeni araçlarla birlikte yeniden icat etme yoluna gitmişlerdir. Yüzyılın başlarında tasarımcılar, avangart sanat hareketlerinin uzantısı olarak basılı mecralarda sanatsal estetiği işlevsellikle birleştiren çalışmalar yapmış ve topluma daha yakın durmayı tercih etmişlerdir. Bu dönemlerde özellikle soyut sanatın biçimsel 
özellikleri tasarımın ana dili haline gelmiştir. 1950’ler sonrasına, İkinci Dünya Savaşı' nın da etkileriyle grafik tasarımcılar arasında idealist bir biçim yaratma hissi doğmuş, grafik tasarımı daha açık ve demokratik bir biçimde yeniden düşünülmesi gereken bir alan olarak görmüşlerdir. Modernist çalışmaların sistematikleştirildiği bu dönemde hızla yayılan Uluslararası Tipografik Üslup ile modern dünyanın iletişimi yalınık üzerine kurulmuştur.

Modern grafik tasarımın başlıca belirleyicisi olarak kabul edilen Uluslararası Tipografik Üslup ile dönemin grafik tasarımcıları problemin çözümüne dair en yalın ve tarafsız sonuçlar elde etmek için anonim bir tutumla kişisel yorumlardan uzak durmuşlar ve matematiksel sistemler üzerine oturtulmuş tırnaksız yazı karakterleri, asimetrik düzen, boş alanların etkili kullanımı ve fotoğraf ile tipografinin tarafsız birliktelikleriyle çok net bir biçimsel tavır inşa etmişlerdir (Meggs, 2006). Arka plan ile yüzeyde görünenin parçalanamaz bir bütün haline dönüştüğü bu anonim tasarım dilinde tasarımcılar içeriğe herhangi bir müdahalede bulunmadan, yalnızca biçimsel dilin inşasına katkıda bulunan birer (mühendis) aktarıcı olmayı tercih etmişlerdir.

Tasarımcının bireyselliğini ön plana koyduğu tasarımda post yapısalcı dönem, 1970’lerde modernizmin evrensel diline bilinçli bir tepki olarak ortaya çıkmıştır. Biçimsel değişimin de ötesinde, tasarımcılar arasında teorik söylevler tartışmaya açılmıştır. Modernizmin biçim işlevi izler ilkesi ters yüz edilmekle birlikte işlevi hiçe sayan, mesaj iletme kaygısına zıt bir tavır ortaya konmuştur. Neden sorusu gün yüzüne çıkmış ve üretilen her iş kendi içerisinde bir sorguyu kapsamına almıştır (Drucker ve McVarish, 2009).

Postmodern dönemle birlikte tasarımın işlevi, anlamı ve alıcı kitlesi dahi değişmiştir. Grafik tasarım artık yalnızca basit bir iletişim kanalı olmaktan çıkıp, mesajın önemli bir parçası haline dönüşmüş ve kendi kelime dağarcığı ve anlam kümesiyle kendine özgün bir dile sahip olmuştur. Tasarımcılar da kendi yorumlarını sergileyebilecekleri kişisel ifade biçimlerinin peşinde koşup tasarımın kelime dağarcığını daha da genişletmeye çalışmışlardır (Poynor 1998, s. 235236).

Postmodern dönemin grafik tasarımcıları anlamın birden çok yolunu aramaya koyulmuşlardır. Analitik biçimde karakterize edilen bir üsluba sahip olan modernizmin aksine postmodernizm, metinsel alıntılarla dolu farklı üslupları içinde barındırmaktadır. Postmodern dönemde işlevsellik anlayışı yerini anlamsal arayışlara bırakmış, modern dönemde problem çözücü olan grafik tasarımcı, postmodern dönemde kendisini problemi ortaya koyan kişi olarak konumlandırmıştır. Strom'a (2003) göre artık içeriğin tasarım sürecine dahil olmasıyla tasarımda ana anlatının kaynağı olan metnin anlam yapısı artık salt form ve grid sistemine sadık kalmak zorunda değildir.

Geleneksel devamlılığın yıkıldığı 1970 sonrası grafik tasarım dünyasında kavramsal sanat hareketleri de tasarımda içeriğin yeniden şekillenmesini tetiklemiştir. Anlaşılırlı üzerine olan iletişim doğası, yerini karmaşaya ve çok katmanlılığa bırakmıştır.

1970 sonrasında, modernizmin tekil karakterinin tersine çoğulcu, eklektik, tüm yeni ve karmaşık yaşamsal koşullandırmaları, yaşamın çoğul karakterini, değişen dünya düzenini ve her şeyden içine biraz alan postmodern süreç başlamıştır. Bu süreç, postyapısalcı, postmodern, dekonstrüktivist kavram ve saptamalar ışığında birçok sanat disiplininin kaynaştığı ve sınırsızlaştığı bir ortamda gerçekleşmeye başlamıştır (Öztuna, 2007, s. 79).

Sanatı ve tasarımı birbirinden ayıran sınırların 1980'ler ile birlikte yavaş yavaş incelmeye başladığını söyleyen Öztuna, aynı zamanda içeriğin, tasarımın ayrılamaz bir parçası haline geldiğini, dolayısıyla tasarımcının konumunun yazarla eş tutulduğunu da dile getirmektedir:

İçeriğe bağlı tasarım öğelerinin kodlaması ve dizilmesi, o sayfaya ait içeriğinden referansla bir araya gelmektedir. Bu yerleştirme, süslemeden öte yorumda bulunma odaklı gerçekleşmektedir. Tasarımı oluşturan her bir parça, onun anlam bütünlüğünün katmanlarıdır ve tasarımı bir arada tutmaktadır. İçeriği doğrudan referans alınıp tasarımla yeniden yorumlanan çalışmalarda tasarımcı bir çeşit yazar ya da editör olmuştur (Öztuna, 2007, s. 81).

Postmodern dönem grafik tasarımda içerik ve biçim ilişkisi birlikte çalışmaktadır. Üstelik içeriğinden ayrı olarak işin kendisi de bir anlam taşımakta ve okuyucu da anlam okumasına dahil olmaktadır (Huswit, 2007). Tasarım izleyiciyi aktif katılımcıya dönüştürmekte ve tasarlanan iş üstüne yeni anlamlar katmaya teşvik etmektedir. Bu bağlamda tasarımda modernizmin dayattığı geleneksel ve katı tipografik kurallardan vazgeçilmiş, izleyiciyi yeni okumalara yönlendirebilen çok katmanlı ve çok anlamlı bir biçim anlayışı benimsenmeye başlanmıştır. Modernist grid 
sisteminin tipografik anlatıya getirdiği sınırlı imkân ortadan kalkarak biçimsel ifade haznesi genişletilmiştir. Artık içerik, tasarımın merkezine oturmuş; izleyici okuyucuya, imgeler okunana, yazılar da bakılana dönüşmüştür.

\section{Bireysel Yorumların Öne Çıkışı}

Grafik tasarım alanında resmi anlamda postmodern hareket, Wolfgang Weingart’tan ilham alan öğrencilerin 1970’li yıllarda bilinçli bir seçim olarak Uluslararası Tipografik Üslup'u reddetmeleriyle başlamıştır. Weingart, tipografiyi yalnızca metni okutmaya dayalı, belirli sayıda harf ölçüleriyle kullanılmak zorunda olan ve bir sisteme bağlı kalan yapısından çıkartıp, İsviçre tasarım anlayışının sıkı kurallarını terk eden biçimde kullanmayı tercih etmiştir. Weingart'ın bu deneysel yaklaşımı (bkz. Şekil 1), İsviçre tasarım anlayışından koşulsuz bir kopma olarak değil, tasarımın doğal süreci içerisinde sınırlarını esnetmek olarak görülmektedir. Tasarımcının yorumunun dahil olmaya başladığı bu kırılma, Yeni Modern olarak da adlandırılmaktadır. Görsel kompozisyon yaratırken kullanılan analitik yaklaşımların yanı sıra Weingart, bir müellif tasarımcının sahip olması gereken önsezi ve bireysellik fikirlerini de çalışmalarında kullanmıştır (Eskilson, 2007, s. 352-356).

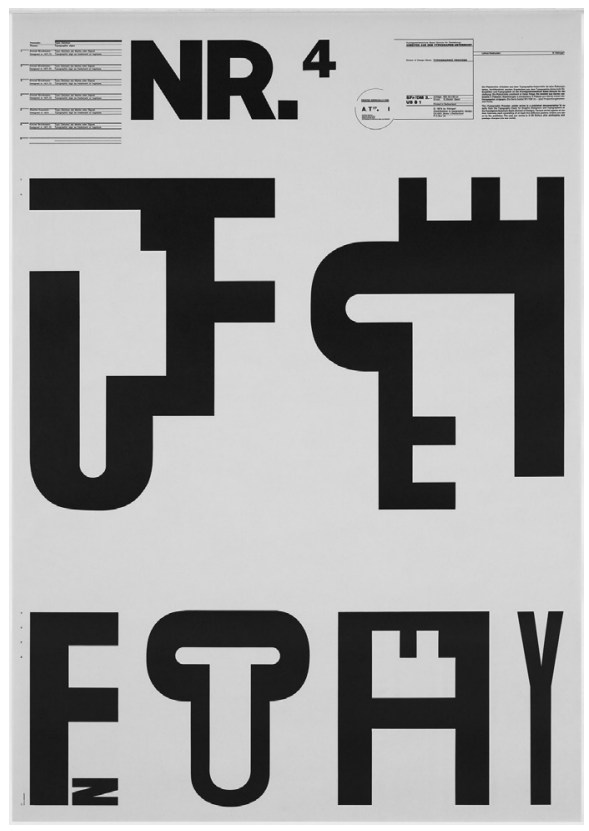

Şekil 1. Typografische Monatsblatter dergisi kapak tasarımı, W. Weingart, 1971-1972.

Wolfgang Weingart'ın sözdizimsel deneyleri ile dönüşüme uğrayan grafik dil, Amerika'daki okullara da tesir etmeye başlamıştır. Grafik tasarımda yeni yapısalcı dil ile birlikte 20. yüzyıl modernizmi yeniden keşfedilmiş ve Yeni Dalga hareketi ortaya çıkmıştır. Cranbrook Sanat Akademisi Grafik Tasarım Bölüm Başkanı McCoy'a (1990) göre Yeni Dalga, klasik İsviçre yapısını, grafik tasarımın dilbilgisini ayrıştırana ve yeniden birleştirene dek genişletilen, katmanlı görseller ve dokularla Kübizm, Konstrüktivizm ve Dada'nın başlattığı kolaj estetiğini devam ettiren bir anlayıştır ve Yeni Dalga'nın karmaşık düzenlemeleri büyük ölçüde sözdizimseldir.

Yeni Dalga (bkz. Şekil 2) ile birlikte grafik tasarımda biçimin, metinin ve imgenin anlamsal ifadeleri yeniden ortaya çıkmıştır. Bunun en büyük sebeplerinden birisi de tasarımcıların sanat, fotoğraf ve edebiyat gibi tasarıma destek olan farklı eğitimlere sahip olmalarıdır. Tasarımcılar, grafik tasarımda biçimsel üslupla birlikte içeriğe dayalı ifadeye de çok önem vermişlerdir. Grafik tasarım çalışmalarında imge ve anlam ayrıntılarıyla okunmaktadır ve bu yeni entelektüel iletişim yöntemi, okuyucusunu da eş yorumcu olarak davet etmektedir.

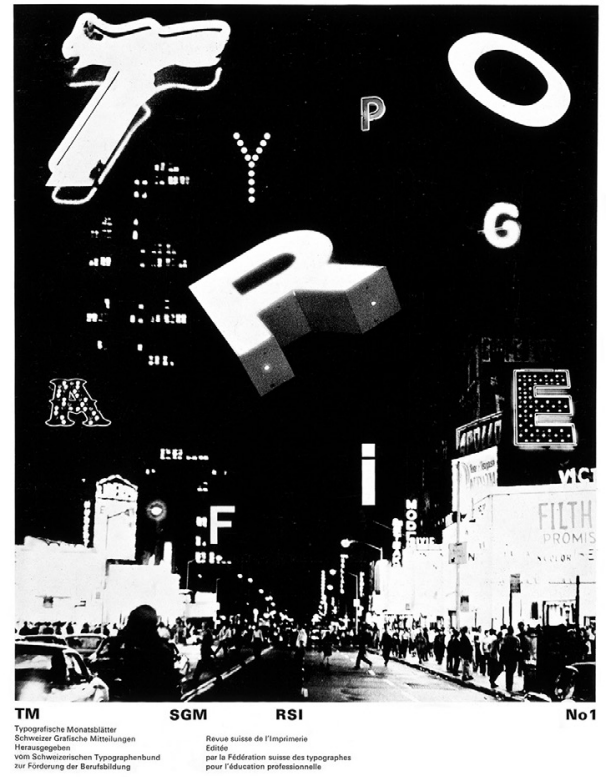

Şekil 2. Typografische Monatsblatter dergi kapağı düzenlemesi, D. Friedman, 1971.

Weingart'ın etkisi, grafik tasarımda postmodern harekete sıkı sıkıya bağlı olan Cranbrook Sanat Akademisi öğrencilerinin çalışmalarında da görülmeye başlanmıştır. Uluslararası üslubu müfredatında barındırmaya devam 
eden diğer birçok sanat okulunun aksine Katherine McCoy, postmodern tasarım anlayışına daha yakın durmuş ve öğrencilerini kişiye özgü fikirleri sergilemeye daha açık olan bu yeni alanı keşfetmeye itmiştir. McCoy için metni okuma ve imajı görme birbirinden ayrılmamalı; aksine, birbiriyle uyum ve etkileşim halinde olmalı ve iki yorumlama bicimi bir bütün olarak ele alınmalıdır. McCoy'un söylem olarak tipografi (bkz. Şekil 3 ve Şekil 4) diye adlandırdığı bu fikir, çalışmanın anlamını oluşturan metin ve imge arasındaki diyalog olarak tanımlanmaktadır (Eskilson, 2007, s. 352-356).

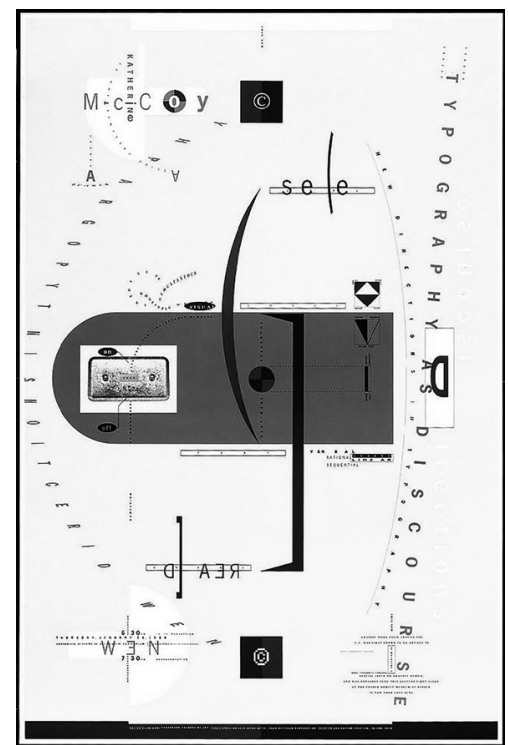

Şekil 3. Typography as Discourse, A. Hori, 1989.

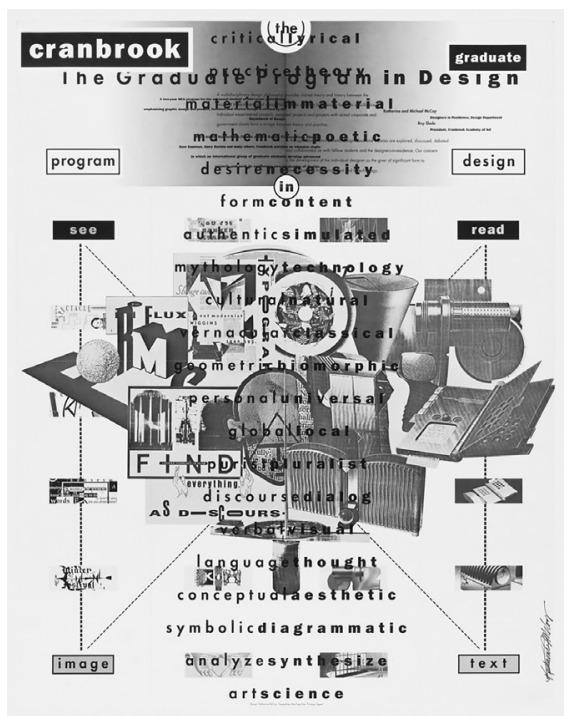

Şekil 4. Cranbrook Sanat Akademisi Broşürü, K. McCoy 1989.

McCoy’a göre yapıbozumculuk, anlamı tek yönlü olmayan, tek kaynağı ve alıcısı da olmayan, anlamının izleyicinin katılımıyla şekillendiği bir iletişim modelidir. McCoy, tasarımcıyı problem çözmenin ötesine geçiren, ek içerik üreterek mesajın öz eleştirisini yapan ve hatta sanat ve edebiyatla ilişkili rollere bürünen bir kişi olarak görmektedir. Böylelikle tasarımcı, metinden belli bir ölçüde mesajı sahiplenebildiği müellif konumuna yerleşebilmektedir.

\section{Bir Grafik Tasarım Dili Olarak Dijital Dışavurum}

Tasarımda anlam ve söylem önem kazanmaya başlamışken, tasarımcılar aynı zamanda değişen dünya düzeni ile birlikte kendilerini yeni bir kimlik arayışına doğru yönlendirerek gelişen teknolojilerin sunduğu imkanlarla da yüzleşmek zorunda kalmışlardır. Postmodern dönemin karmaşık ve katmanlı tasarım yapısı, teknolojinin tasarımcılara sunduğu yeni dünya ile dijital dişavurumculuğu bünyesine dahil etmiştir. 1970’li yıllarda Apple Macintosh bilgisayarlarının bireysel tasarım aracı olarak piyasaya sürülmesiyle birlikte grafik tasarımcılar dijital formları potansiyel grafik estetiği olarak dikkate almaya başlamışlardır. Tasarımcıların laboratuvarları artık masanın üzerindeki bilgisayardır ve buna paralel olarak masaüstü yayıncılık terimi ortaya çıkmıştır. Bilgisayarın programlama dilini kullanma biçimi ve sınırlı sayıda piksel tabanlı yazı karakterleri, çok katmanlı tipografi ve imaja dayalı çalışmaların temeli olmuştur. Amerikalı tasarımcı April Greinman, bilgisayarın biçimsel dilini kendi tasarımlarında kullanan ilk isimlerdendir. Basel School of Art'da Weingart'ın öğrencisi olan Greinman, kendi işlerinde Weingart'ın karmaşık ve zengin tipografik anlatısını, ilk dönem Apple Macintosh bilgisayarların imge yaratma işleviyle birleştirmiştir (Cramsie, 2010, s. 314-315).

Design Quarterly adlı derginin özel sayısı için yaptığı sayfa tasarımı (bkz. Şekil 5), grafik tasarımda dijital göstergelerin kullanıldığı ilk örneklerdendir. Greiman'ın gerçek vücut ölçülerinde olan ve dijitalleştirilmiş çıplak vücudunun hâkim olduğu $60 \times 240 \mathrm{~cm}$ uzunluğundaki sayfa, güneş sisteminin başlangıcından Apple bilgisayarın icadına kadar olan teknolojik gelişmelerin periyodik cetvelini içermektedir. Sayfanın zemini ise renkli video oyunlarından imajlar ve afişin üretim anındaki teknik işlem sürecini içeren notlarla doldurulmuştur. Sayfa, o dönem için tek bir bilgisayardan basılabilen en büyük ve detaylı grafik çalışmalardan birisi olarak tarihe geçmiştir (Cramsie, 2010, s. 314-315). 


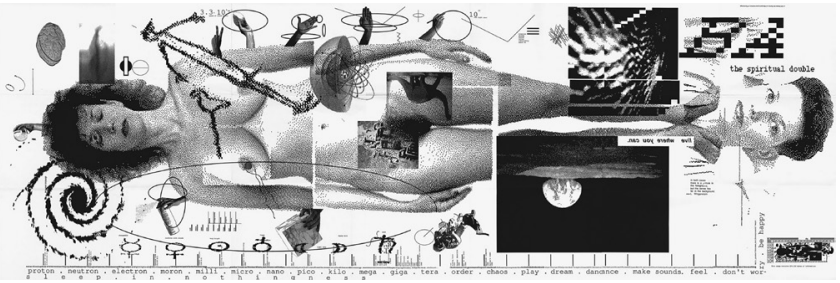

Şekil 5. Design Quaterly, A. Greiman, 1985-1986.

Greiman bilgisayarı bir işleme aracı olarak görmekten öte, insan bilincine sızan bir yaratım aracı olarak kullanmayı tercih etmiştir. Modernizmin kusur kaldırmayan üslubunun aksine okunurluk ve sadelik anlayışı, postmodern tasarım çalışmalarının estetik ifade boyutunu genişletmek adına feda edilmiştir. Dönemin hissiyata dayalı tasarım kararlarının sonucu olarak bilgisayarın kusurlarını kasten içerisinde barındıran çalışmalar, tasarımcıların yeni görsel ifade dili haline gelmiştir (Eskilson, 2007, s. 356).

\section{Editoryal Tasarımın İlk Örnekleri}

Bilgisayar estetiğini ve dijitalleştirilmiş yazı karakterlerini tasarımlarında kullanmaya başlayan diğer isimler 1984'te Emigre tasarım topluluğunu kuran Hollandalı Rudy VanderLans ve Zuzana Licko olmuştur. İkili, Amerika'ya göç eden Hollandalı tasarımcılar ile birlikte modernizme bir karşı duruş olarak Emigre (bkz. Şekil 6) isimli dergiyi çıkarmışlardır. İçerisinde tasarımcıların makalelerinin ve çalışmalarının yer aldığı derginin tasarım kararları gelenek yıkıcı, kopuk ve karmaşık olma özelliği taşımaktadır (Eskilson, 2007, s. 364365).

Rudy VanderLans'ın tek başına editörlüğünü, tasarımını ve yayımcılığını üstlendiği bir dergi olan Emigre, tasarımcının kendi sözünü istediği bicimde söyleyebildiği, 1980 ve 90’larda deneysel ve teknolojik potansiyellere sahip yeni grafik tasarımın özgür tartışma alanına dönüşmüştür. Dergi, tipografik yaklaşımıyla da içeriğine bağlı bir grafik forma sahiptir. Emigre'de yer alan her makale, Zuzana Licko tarafından tasarlanan birçok farklı dijital tabanlı yazı karakteriyle dizilmiş ve bu yolla tartışmalara farklı sesler atfedilmiştir. Ayrı konuları içeren makaleler, farklı fontlarla ve yerleştirildikleri farklı boyutlardaki yazı bloklarıyla dergi boyunca eş sesli ilerlemektedir. Derginin sayfa tasarımı anlayışı, birbirleriyle zıt görüşe sahip içeriklerden oluşan derginin kendisini, karşılıklı konuşma ortamının bir parçası haline getirmektedir (Cramsie, 2010, s. 316-317).
Bilgisayar teknolojisi, üretimde bütünleşmenin yanı sıra uzmanlaşmaya da olanak sağlamaktadır. Günümüzde belirli bir alanda uzmanlaşmak için daha az dış bilgiye ve yeteneğe ihtiyaç duyulmaktadır. Örneğin, bir harf tasarımcısından aynı anda hem yetenekli bir harf dökümcüsü hem de yaratıcı bir zihne sahip olması beklenmemektedir. Üstelik disiplinlerarası geçişe olanak sağlayan daha iyi bir iletişim olanağı da mümkün. Tasarımcılar, dışarıdan bir dizgiciye veya renk ayrımcıya ihtiyaç duymadan tasarım ve üretimin tüm adımlarını kontrol edebilmektedir. Metin düzenleme ve sayfa tasarımı, eş zamanlı olarak tek bir mecranın üzerinde yürütülebilmektedir. Dolayısıyla yayımcılıkta tasarımcının, yazar ve editörün tüm işlevlerini bireysel olarak üstlenebilmesi ve tüm bu disiplinleri bir araya toplayabilmesi artık mümkün hale gelmiştir (VanderLans ve Licko, 1989).

VanderLans grafik tasarımı, bir sanatçı ve yazarın sezgisel dışavurum mecrası olarak görmüştür. Modernizmin mühendis gibi davranan tasarımcı modelini reddeden VanderLans, her bir çalışmaya bireysel imzalarını atan müellif tasarımcı fikrinden yana olmuştur (Eskilson, 2007, s. 364-365).

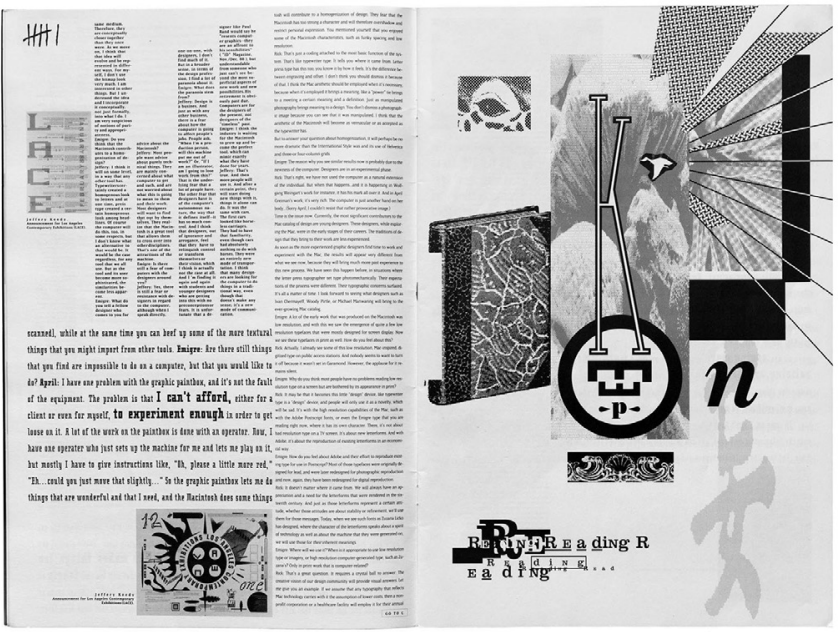

Şekil 6. Emigre dergisi, 11. Sayı, 6 ve 7. sayfalar, R. VanderLans, 1989.

\section{Yeniden İnşa İçin Yapıbozum}

Grafik yazarlıkla doğrudan ilişkisi olan yapıbozumcu yaklaşım, 1980'lerin ortasında grafik tasarım gibi mimarlık, endüstri ürünleri ve edebiyatta kendisini göstermeye 
başlamıştır:

Yapıbozumculuk, daha çok metinlerin oluşumunu ortaya koyan dilbilimsel ve temel sistemler üzerinde yoğunlaşmıştır. Yapıbozumculukta yazı, bir şeyi ifade etmenin edilgen değil, etkin bir yolu olmuştur. Roland Barthes, Michel Foucault, Jean Baudrillard ve diğerlerini içine alan, eleştirel bir alan olan post-yapısalcı yazarların ifade türlerini sosyal dünyayı inşa eden ve tekrar yapılandıran güçlü teknolojiler olarak kabul etmişlerdir (Lupton ve Miller, 1999, s. 348).

Yapıbozumcu grafik tasarım, reddettiği sınırları yok etmekten öte onları yeniden yazarak inşa etmeyi amaçlamaktadır. Grafik tasarım alanında üretilen çalışmalar da bu bağlamda işin edebi ve felsefi taraflarıla da ilgilenmeye başlamıştır. İçeriği yeniden yazma girişimi, formun da yeniden yapılandırılması anlamına gelmektedir. Dil ve imge, anlamın katmanlarını ve dilin karmaşıklığını okuyucuya görsel detaylar arasında okunabilen daha karmaşık ve uzun süreli bir tasarım yüzeyi sunmaktadır. Temeli metin ve anlam ile kurulmuş olan yapıbozumcu grafik tasarımın en temel ve uygun malzemesi de tipografinin kendisidir (Poynor, 2003).

Yapıbozumcu grafik tasarımcılar, anlamı tek kaynaklı olmaktan çıkartarak metinlerle ilişkilendirmişlerdir. Eleştirel bir sorgulama süreci olan yapıbozumcu grafik tasarımda çok yönlü ve doğrusal olmayan anlamlar yaratan grafik tasarımcılar, tasarımda estetik ve okunur olma kaygısını tartışmaya açmışlardır. Hem metinlerarasılık hem de çok parçalı biçimsel düzenlemeler, beraberinde bu yeni yapının teorisini de gündeme getirmiş, tasarımcılar da kendilerini bu biçimsel teorinin yaratıcısı olarak görmüşlerdir (Poynor, 2003).

Dijital evrim ile birlikte bu evrimin tüm araçlarını görsel bir deneyim olarak kullanan grafik tasarımcılar, bilgi ve nesneyle karşı karşıya gelen insanların anlamı nasıl inşa ettiklerini göz önünde bulundurmuşlardır. Tasarım, postmodern dönemle birlikte üzerine düşünülen, tepki verilen ve yeniden yorumlanan bir model haline dönüşmüş ve tasarımcılar ile tüketiciler, bu modelin ortak katılımcıları olmuşlardır.

Diyalog, söylem, tartışma ve dönüşümü içerisinde barındıran yeni tasarım kritikleri, tasarımcı, ileten ve alıcı arasındaki anlam kaynaklı alışverişi genişletmiştir. Tek yönlü olmaktan çıkan mesaj, bilgiyi üreten ve onu okuyanın arasındaki çok yönlü iletiyle yeniden yapılandırılarak yeni anlamlara açık hale dönüştürülmüştür (McCoy, 1998).
Tasarımcının yazar gibi işlevi olan ve aynı zamanda otoritesini reddettiği düşüncenin temelinde ise geleneksel ileten-verici-alıcı iletişim modelinde köklü bir değişim söz konusudur. Karol'a (2007) ${ }^{2}$ göre ileten, önayak olan kimsedir. Yani mesajı devreye sokan ve resmi olarak sahibi olan kişi. Verici hem kullanılan mecra hem de tasarımcının kendisidir. Tasarımcı, mesajın yazarıdır. Alıcı da okuyarak ve yorumlayarak mesajı yeniden yazan kişidir. Yorumlayan alıcı, soru ve görüşler ileri sürer ve dolayısıyla bu yeniden yazma eylemi, alıcıyı yeni mesajların göndericisine dönüştürmektedir.

Tüm bu biçimsel ifadenin süregelişinde tasarımcılar grafik tasarım ürünlerindeki mesajın üretilmesine katkı sağlayan (ve hatta mesajın kendisini üreten) yorumcu, katılımcı ve yazar olarak yeni bir konuma sahip olmuşlardır (McCoy, 1998). Tasarımda anlam ve içerik, tasarımcı ve -yeni yorumlayıcı olarak- okuyucu tarafından yeniden inşa edilmeye yönlendirilmiştir. Grafik tasarımda yazarlık yöntemi, içerik ve anlam ortaya çıkartarak formu iki boyutlu bir yüzey olmaktan öteye geçirmiştir (Lupton, 1997).

\section{Tasarımda Bugünün Yazarlığı}

Barthes, yazarın ölümünü, yazarın metnindeki anlamın her okuyucuya göre değişebileceği dilbilimsel bir fikre dayandırmaktadır. Dolayısıyla tekil bir anlamdan ve bu anlamın kanallı iletişiminden söz edilememektedir. Modernizm dönemi tasarım tavrı bu görüşün tam aksini savunmaktadır. Mesaj tek taraflıdır ve mutlak, değişmeyen bir anlam aktarımı söz konusudur. Ancak postmodern tasarım anlayışında ise anlam işi izleyen tüketiciye bırakılmıştır. Tasarım ürününün yalnızca tek bir mesajı tek bir kanaldan iletmek gibi bir yükümlülüğü ortadan kalkmıştır.

İdeolojik ve estetik bağlamda grafik tasarımcılar, yirminci yüzyılda grafik tasarım mecralarının kalitesini yükseltmiş; Avangart sanat hareketleriyle batı toplumunun sanat anlayışını altüst etmiş, Uluslararası Tipografik Üslup ile müşteriler için evrensel ve modern bir çözüm üretmiş, postmodern dönemde ise bir yazar gibi davranıp modernizmin bu tutucu ve tüketime dayalı tavrını reddederek teknoloji, edebiyat ve felsefe ile grafik tasarımda hem içeriğe dair hem de biçime yönelik yeni denemeler peşinde koşmuşlardır. 1970 öncesi tasarımda yerleşik geleneğe karşı çıkarak;

22007 yılında yayımlanan Sending off bottles to the sea isimli bu makale artık çevrimiçi kaynaklarda bulunmamaktadır. Esen Karol ile yapılmış kişisel görüşme aracılığıyla kaynağa ulaşılmıştır. 
içeriğin üretim sürecine dahil olan bir yazar ve biçimsel imzalarıla bir üsluba ve tavra sahip birey olan grafik tasarımcılar, artık rollerinin daha da bireyselliğe ulaştığı bir yerde durmaktadırlar.

Günümüz grafik tasarım üretimlerinde Barthes'in işaret ettiği dilbilimsel anlayışı görsel dilde bulmak mümkündür. Ed Fella, David Carson, Stefan Sagmeister, Jonathan Barnbrook gibi postmodern dönemin tasarım eğitimiyle yoğrulmuş grafik tasarımcıların yolunu açtığı süperstar tasarımcı eğilimi bugün halen varlığını korumaktadır. Carson, doğru iletişim kurmanın yalnızca okunur olandan geçmediğini, okunaksız veya karmaşık bir tasarımın da iletişim kurabildiğini ifade etektedir. "Bir şeyin okunabiliyor olması, onun doğru iletişim kurduğu anlamına gelmez. İletişimi okunabilirlik ile karıştırmayın” der Carson (2003). Bu görüş, grafik tasarımcıların kendilerini biçimsel olarak ifade ederlerken büyük bir özgürlüğe sahip olabilecekleri müjdesini vermektedir. Anonim olan tasarımcının, tekil ve bilinen tasarımcı olması için önünde bir engel kalmamıştır. Tasarımcı, artık içeriği doğrudan ileten bir aracı değil, içeriği maniple edebilen bir yorumcudur.

2000’ler sonrası grafik tasarım dünyasına bakıldığında, bir önceki kuşağın açtığı bireysellik ve özgürlük alanını, kendisini yazar olarak görmenin de ötesinde, küratör veya editör tavrına sahip grafik tasarımcılardan söz etmek mümkündür. Fraser Muggeridge, Danile Eatock, Åbäke, Werkplaats Typografie, James Langdon gibi tasarımcılar ve topluluklar, tasarımda görsel dili, editoryal yaklaşım ile birleştirip entelektüel bir diyaloğa çevirmektedirler. Bunu yapabilmelerinin en önemli sebebi de sanatsal ve kültürel alana hizmet edip orada var olmalarıdır. Ürettikleri grafik tasarım ürünlerini, ilişkili oldukları sanatsal içerik ile sıkı sıkıya bağlı bir yapıda kurmayı önemseyip, nasıl ki 70^lerden 90^lara kadar uzanan dönemde yazarın rolünü ödünç alıyorlarsa, günümüz tasarımcıları da sanatçıların ve küratörlerin rollerini ödünç almaktadırlar. Tasarım ve sanat arasındaki keskin ayrımdan bugün söz etmek pek mümkün değildir. Tasarımcı, sanatçı veya küratör gibi düşünmekte, tasarım ürünleri de sanatsal bir bakış açısıyla zenginleşebilmektedir. Ticari kaygılar, kuşkusuz iletişim, şeffaf iletkenlik gibi grafik tasarımı katı şablonlar içerisine sıkıştıran tavırlardan kurtulup, tasarlama eylemini daha entelektüel bir girişim olarak görmenin vakti çoktan gelmiştir. Artık günümüzde tasarımcılara yalnızca tüm gerekli donanımları kullanabilme kabiliyetinden dolayı değil, belirgin dünya görüşüne sahip ve güçlü ideolojik duruşlarıyla söyleyecekleri bir şeyler olduğu için ihtiyaç duyulmalıdır.

\section{Kaynakça}

Barthes, R. (2013). Yazarın ölümü (A. Ece, N. K. Sevil, ve E. Gökteke, Çev.). Dilin çalışma sesi içinde. İstanbul: Yapı Kredi Yayınları.

Carson, D. (2003). Design and discovery. TedTalks. Erişim adresi: $\quad$ https://www.ted.com/talks/david_carson_on_ design?language $=$ tr

Cramsie, P. (2010). Printing with pixels, the story of graphic design. New York: Abrams Publishing.

Drucker, J. ve McVarish, E. (2009). Graphic design history: A critical guide. Amerika: Pearson Education.

Eskilson, S. (2007). Mature postmodernism Wolfgang Weingart graphic design a new history. Londra: Yale University Press.

Foucault, M. (1998). What is an author? In Faubion J. D. (Ed.), Aesthetics, method and epistemology, essential works of Foucault, 1954-1984 (R. Hurley and others, Trans.) New York: The New Press.

Friedman, D. (1971). Typografische Monatsblatter [Dergi kapağı]. Erişim adresi: http://www.tm-research-archive.ch/ issue/1971-1/

Greiman, A. (1985-1986). Design Quaterly. Erişim adresi: https:// cultureofdesign.files.wordpress.com/2014/05/10162_g_ original.jpeg

Hori, A. (1989) Typography as Discourse [Afiş]. Erişim adresi: https://farm3.staticflickr.com/2814/10964340805_49dde0 3c70_b.jpg

Huswit, G. (Yönetmen). (2007). Helvetica a documantery film. [Film] İsviçre: Swiss Dots Production.

Karol, E. (2006). Sending off bottles to the sea. Kişisel görüşme ile ulaşılan kaynak.

Karol, E. ve Tanyeli, U. (2007). Esen Karol ile Uğur Tanyeli arasında bir e-posta söyleşisi. Kişisel görüşme ile ulaşılan kaynak.

Lupton, E. (1997). A postmodern on deconstruction? Design culture an anthology of writing from the AIGA journal of graphic design. In Heller, S., Finamore M. (Ed.) New York: Allworth Press.

(1998). The designer as producer, the education of a graphic designer. In Heller, S. (Ed.) New York: Allworth Press. 
(2009). Insights design lecture series: Ellen Lupton. Walker Art Center: Minneapolis. Erişim adresi: http://www.youtube. com/watch?v=6u0_K6t8wUE

Lupton, E. ve Miller, A. (1999). Deconstruction and graphic design, design writing research. New York: Phaidon.

Meggs, P. (2006). Meggs' history of graphic design. New Jersey: John Wiley \& Sons, Inc.

McCoy, K. (1989). Cranbrook Sanat Akademisi Broşürü. Erişim adresi: https://66.media.tumblr.com/03bd5c9f76f81a29e f0a243489825e46/tumblr_nzqvmmVLDW1spitb2o1_1280. jpg

(1990). Cranbrook design: The new discourse. Hugh Aldersey-Williams (Ed.) ABD: Rizzoli International Publications

(1998). Digital communications design in the second computer revolution. Erişim adresi: https://shahkaarrizvi. files.wordpress.com/2011/11/essays.pdf

Öztuna, Y. (2007). Yapıbozumculuk ve grafik tasarım. Grafik Tasarım Dergisi, 15, 79-85.

Poynor, R. (1998). Design without boundaries: Visual communication in transition. Londra: Booth Clibborn Editions.

(2003). No more rules: Graphic design and postmodernism. Londra: Yale University Press.

Rock, M. (1996, Spring). The designer as author. Eye Magazine. Erişim adresi: http://www.eyemagazine.com/feature/ article/the-designer-as-author

Strom, K. (2003). Reading Scott Makela: The subversion of dyslexic deconstruction. Design Issues, 19(2), 5-16. Erişim adresi: https://www.jstor.org/stable/1512013?seq=1\#metadata info_tab_contents

VanderLans, R. (1989). Emigre [11. sayıdan 6 ve 7. sayfalar]. Erişim adresi: https://letterformarchive.org/uploads/ Editorial8200.jpg

VanderLans, R., Licko, Z. (1989). Emigre ambition/fear. Erişim adresi: https://www.emigre.com/assets/file/pdfMagazine/ Emigre11AmbitionFear.pdf

Weingart, W. (1971-72) Typografische Monatsblatter [Dergi kapağ1]. Erişim adresi: https://www.moma.org/collection/ works $/ 86506$ ?artist_id $=6289 \&$ locale $=$ en $\&$ page $=1 \&$ sov_ referrer=artist 